\title{
Sovereign Wealth Fund and Economic Growth in Nigeria: An Empirical Analysis
}

\author{
Oleka, Dorothy Chioma ${ }^{1}$, Ugwuanyi Boniface Uche ${ }^{2}$, Ewah, Evelyn Bassey ${ }^{3}$ \\ 1 Department of Banking and Finance, Enugu State University of Science and Technology, Enugu Nigeria \\ 2Department of Accountancy, Enugu State University of Science and Technology, Enugu Nigeria \\ 3Department of Banking and Finance, Godfrey Okoye University, Enugu Nigeria
}

\begin{abstract}
This paper evaluates the sovereign wealth fund of Goodluck Jonathan of Nigeria administration with a view to empirically examine the factors that affect its creation and operations vis-à-vis its impacts on the growth of the economy. Both primary and secondary data were used in this study. The study was guided by five research objectives. All the 40 staff of Nigerian Sovereign Investment Authority (NSIA) in the state constituted the target population. A purposive sampling technique was used to select 30 staff of the establishment for the study. Mean scores and standard deviation were used to answer the research questions. Parametric statistics in forms of analysis of variance-ANOVA, co-efficient of correlation and simple linear regression were used to analyze the hypothesis. We determined the effect of SWF on the economic growth using gross domestic product as a major economic performance indicator. The study found that the link between SWF and economic growth in Nigeria is statistically significant but not positive. The reason is because the sovereign wealth fund is new in Nigeria, coupled with several challenges facing its operations hence has not contributed much to the GDP growth rate of the economy. Some remedial measures were suggested which include the need to ensure that the financial and operational independence of the organs of the NSIA be guaranteed by statute; the NSIA and its organs must be shielded from undue political influence through well defined administrative and operating procedures and that transparency and accountability in reporting must be seen as major watch words of the Fund.
\end{abstract}

Keywords: Nigeria, Sovereign wealth fund, Investment, NSIA, GDP, Economic growth.

\section{Introduction}

As the name suggests, sovereign wealth fund (SWF) is an array of financial reform inform of instrument owned by a sovereign state, where a nation's savings are accumulated for foreign direct investment and development purposes. A sovereign wealth fund is a federal government reform which serves as a source through which many countries source revenues for development and economic growth of their countries through foreign direct investment, (Elko and Barnard 2008). The sovereign wealth fund has benefited so many economies especially the developed countries that have surplus reserves. For this fund, the primary focus is on the development of a foreign portfolio of investments of a sovereign state. This term was described by Romanov (2005) as fund which is created from foreign exchange reserves earned by a sovereign state to meet specific purpose. Gbogbo (2013) defines sovereign wealth fund (SWF) as a state-owned investment fund investing in real and financial assets such as stocks, bonds, real estate, precious metals. In alternative, it can assume the form of investments such as private equity fund or hedge fund invested globally. To throw more light on the definition, the International Working Group of sovereign wealth fund (IWG, 2008) defined sovereign wealth fund as a special purpose investment fund or arrangement that is owned by central government in foreign economies.

Hassan (2009) defines sovereign wealth funds as government investment vehicles funded by foreign exchange assets that are managed separately from official reserves. They seek higher sales of return and may be invested in a wider range of asset classes than traditional reserves. Anderson, (2010) noted that the major reasons for establishing sovereign wealth funds (SWFs) stem from the fact that central banks have learned from earlier experiences that it is better to have a substantial amount of money in the foreign exchange accounts. They realized that if sufficient cash is available in readily accessible foreign accounts then it could help the government during the fiscal crisis, currency devaluation, natural economic emergency and even change in the government. Sovereign wealth fund generally falls into two categories based on the countries' sources of foreign exchange assets -commodity and non-commodity funds, (Barney, 2001). The major sources of funding of sovereign wealth fund come from oil income or non-commodities income. For example, the oil producing regions that involved in the reform have utilized their oil income to establish sovereign wealth fund (SWFs) whereas other non-oil producing nations like China and Singapore that are non-commodity based income are funded from trade surpluses. Sovereign wealth fund serves the purpose of having enough liquidity to meetshort-term requirements while investing remaining excess securely in low return investments globally. The pool 
of sovereign wealth fund cash is usually separated from currency and liquidity management (Lam and Rossi, 2001; Kottler and Lei; 2011). Jen, (2007) noted that the key traits of sovereign wealth fund (SWFS) include high foreign currency exposure, lack of explicit liabilities, high risk tolerance and long investment horizons. The sovereign wealth fund investment choices and asset allocation strategies may create negative financial implications worldwide, for example, increasing investment in risky businesses for high returns may reduce liquidity issues in market for low risk businesses or less inclined investment strategy for high technology, research and developmental based industry in the investee country, (Fernandez and Eschweiler, 2008). Thus, growth and investment strategy of sovereign wealth fund has influence on their industries and markets considering their bilateral relations and how much investment sovereign wealth funds would allocate considering the risk and return balance. Now, the question is, how can SWF act as a catalyst and channel for economic growth in Nigeria owning to the fact that it has just been newly created?

Ventures, (2013) noted that the Nigerian Sovereign Investment Authority (NSIA) has just been newly created to manage the Nigeria sovereign wealth fund from excess oil reserve. The sovereign wealth fund was founded for the purpose of managing and investing these funds on behalf of the federal government of Nigeria. The sovereign wealth fund was set up by the Nigeria Investment Authority Act (NIAA) which was signed in March 2011 and it commences full operations in October 2011. It is intended to invest the savings gained on the difference between the budgeted and actual market prices for oil to earn return that would benefit future generations of Nigerians (Gbogbo, 2013). The fund was allocated an initial \$ 1 billion USD in seed capital. To buttress this, Ujah (2013) noted that the initial fund to be managed by Nigerian Sovereign Investment Authority should be the equivalent of the sum of USD \$1 billion, contributed by the three levels of government in Nigeria - the federal the state and the municipal council. Also the Act provides that subsequent funding shall be derived from residual funds from the federation account provided that the derivation portion of the revenue allocation formula is not included as part of the funding. The Nigeria's sovereign wealth fund is comprised of three distinct funds known as windows, each with specific investment and development objectives. 85 percent of the fund would be distributed among the three windows with an initial 15 percent of $\$ 150$ million remaining unallocated to be assigned to any of the three funds as needed in the future. The funds will be invested in various securities across border and the stabilization fund was allocated an initial $20 \%$ while $40 \%$ each went to the future generation and the Nigeria infrastructure funds. The SWF pools of money are derived from a country's reserves which are set aside for investment purposes that will benefit the country's economy and citizens.

Ujah (2013) postulated that the funding for a sovereign wealth fund comes from central bank reserves that accumulate as a result of budget and trade surpluses, and even from revenues generated from the exports of natural resources. To add to these, Gbogbo (2013) noted that the sovereign wealth funds (SWFs) are equally established out of balance of payment surpluses, official currency operations, the proceeds from privatizations, fiscal surpluses and receipt from commodity exports. Most SWFs are funded by revenues from commodity exports or from foreign exchange reserves held by central bank. Some sovereign wealth funds may be held by a central bank, which accumulated the funds in the courses of its management of a nation's banking system; this type of fund is usually of major economic and fiscal importance. Other sovereign wealth funds are simply the state savings that are invested for an expected return and this may not have a significant role in fiscal management. However, the types of acceptable investments included in each SWF vary from country to country, countries with liquidity concerns limit investments to only very few liquid public debt instruments while countries with high liquidity profile diversify extensively, (Ujah 2013).

\section{Statement of the Problem}

This study was designed to examine sovereign wealth fund, its ownership structure, challenges, sources of funding, the perceived benefits to the Nigeria economy and the factors affecting its sustainable growth and performance. The worries of this study are vast; in the first place, Nigeria has spent more than half a century after the discovery of crude oil in commercial quantities without establishing a sovereign wealth fund. The costs of this delay in creating SWF to the country in terms of financial, social, economic, human development, revenue generation are quite enormous and cannot be accurately quantified. Secondly, the fact that there is drop in the price of oil revenue have created additional fiscal challenges for the federal government, thereby affecting the allocation of cash to the sovereign wealth funds and this would affect its performance hence a wrong impression as per expected outcomes. More serious is the fact that Nigeria just created her own sovereign wealth fund in 2011; hence the scope covers only three years and this might jeopardize our findings as per its contribution to the economy as it is still new in Nigeria. In support of this, Gbogbo (2013) lamented that despite the increased interest of governments, analysts, central bankers, academics and other SWFs stakeholders, the literatures on SWF are scarce and still in their infancy stage in Nigeria. Moreover, while there are myriads of studies on the effects of sovereign wealth fund on developed economies, there is paucity of studies on the effects of it in developing countries in which Nigeria is one of them. Sequel to this, the long-run real effects of sovereign wealth fund on the economy have long remained controversial and ambiguous in Nigeria. Indeed, 
ascertaining the empirical relevance of the implications of sovereign wealth fund is an important step in assessing both the long/short run costs and the perceived benefits of it to the economy in particular and Nigerians in general. Thus, this study aims to fill a gap, as the handful of empirical studies in this area is USA and European based. Specific empirical evidence from the developing countries is crucial since the developed economies experiences cannot be automatically applied to the emerging environment like Nigeria, hence this study.

\section{Objectives of the Study}

In line with the problems stated above, the main objective of this study was to examine sovereign wealth fund investment, its operations and impacts on the growth of Nigerian economy. Other specific objectives are:

1. To ascertain the ownership structure of the Nigerian SWF

2. To ascertain its sources of funding in Nigeria.

3. To explore the purposes and perceived benefits of sovereign wealth fund

4. To find out the challenges that faced the creation of SWF in Nigeria

5. To determine the relationship between SWF and economic growth in Nigeria.

\section{Research Questions}

The study sought answers to the following research questions:

1. What is the ownership composition of SWF in Nigeria?

2. What are the sources of funding available for sovereign wealth fund in Nigeria?

3. What are the perceived benefits of sovereign wealth funds in Nigeria?

4. What were the challenges that faced the creation of SWF in Nigeria?

5. To what extent has the creation of sovereign wealth fund impacted on the growth of Nigerian economy?

\section{Research Hypothesis} in Nigeria.

There is no significant relationship between sovereign wealth fund (SWF) and economic growth (GDP)

\section{Theoretical Framework of Sovereign Wealth Fund Investment Authority}

In this study, our discussing of the creation of sovereign wealth fund is based on a number of theories. These theories will help to give meaning to the prepositions on the ownership structure, organ-gram, operations, perceived benefits, influential factors and performance of sovereign wealth fund investment in Nigeria.

\section{The Creation of the Sovereign Wealth Fund (SWF)}

The creation of sovereign wealth fund can be traced to the emergence of business management theories of sovereign states investment portfolios. In other words, our understanding of the activities, operations and performance of SWFs in the economy can be found in the many and varied models known as foreign business management portfolio theories, (Veljko and Barnard 2008). However, Rozanor, (2006) noted that the theoretical foundations of sovereign wealth funds are underpinned from various subjects in foreign portfolio business management. According to him such theories reveal the identity of sovereign wealth fund in terms of its creation, myth, source of fund, objectives, structure, benefits and impacts on the economy. These theories explain the factors affecting sovereign wealth fund as it impacts on markets and industries as implications of investments made by the fund. The proponents of these theories expressed that the sovereign wealth fund could impact on nation's economic growth through the catalytic effect of adequate fund injection, regulation, prudence and transparency.

The International Trade Theory is one of the business management theories applied in this context which asserts that international trade is an exchange of capital, goods or services between countries. To support this theory, Barney and Hesterly (2008) noted that international trade represents a major share of gross domestic product (GDP) of an economy and that the factors such as industrialization, advanced modes of transportation, languages/currencies differentiation, globalization, growth of multi-national cooperation and outsourcing activities can impact an international trade. In further support of this theorem, Abdullah in his own work (2009) asserted that increasing international trade is required if countries want stable and vibrant economies as to continue and remain afloat with the on-going globalization saga. Without the international trade, countries would have access to limited goods and services produced within their own country and no access to the products or services from other countries around the globe. Now, trade is carried out using international currency system and exchange rates of currencies during each transaction of export and imports. To meet any trade uncertainties within and outside the country, each nation's central bank attempts to reserve the foreign 
exchange earned through the exports revenues as surplus. Today, the international trade mechanism involves currencies, accounts, standards, central banks, trade unions etc. Each country attempts to reserve the foreign currencies earned through the international trade because she wants to be in the stable conditions of her own currency competing with global strong currencies like US Dollar, Euro and British Pounce Sterling. This foreign exchange reserves will enable such a country to meet the import bills payment demand and in case of any emergency arising within and without the country. For this purpose, countries try to hold the current and capital accounts in surpluses within the balance of payments (BOP) system. Alberola (2008) asserts that foreign currency reserves and gold reserves are considered to be the two major sources of economic stability and wealth creation of nations. Thus, countries with excess foreign exchange reserves go for wealth multiplication or creation as to at least secure earnings on their reserves. This is one of the basic purposes countries with surplus wealth set up the sovereign wealth funds. Hence, SWF has its first root in the foreign exchange reserves generated from favorable international trading system of exports and imports made by the country. Thus, accumulation of foreign exchange plays a crucial role in creating an economic climate for the countries where they can set up SWFs. For example, the World's total currency composition of official foreign exchange reserves (COFERs) has increased from 1390 billion USD in 1995 to 9258 billion at the end of 2010 and gold reserves has increased to more than 19800 billion USD, (Barney and Hesterly,2008). Bahgat (2008) noted that the rapid increases in gold and foreign currency reserves are observed after 2002 and this rise in the reserves growth has become an international policy agenda and is viewed from different perspectives, such as financing of fiscal deficits, increasing reserves of developing region economies, sustainability of foreign exchange funds and low returns within and outside the US. This accumulation of foreign reserves through international trade facilitates formed main sources of funding to SWF. Thus, international trade theory explains the creation of SWF and its income sources. On the other hand, international trade theory with financial management formed international economic system which revolves around the global demand and supply of goods, services and money. However wealth creation from trade surpluses have to be balanced between risks and returns with appropriate assets allocation based on the robust investment strategies of foreign investment portfolio.

The next important theorem to look at in this work is the modern portfolio theory which states that when a government accumulates foreign exchange reserves beyond her threshold of required future import bills and liquidity problems, she turns to increase the wealth by investing these surplus foreign exchange reserves in diversified ways in foreign environments thereby having collection of foreign portfolios of investment. In support of this, Rozanor (2010) explained that this theory has given rise to the countries launching sovereign wealth funds for increasing returns through portfolio diversification. When it comes to returns on the investments in general, it has been observed by Madura (2008) that with increase in the expected rate of returns, the level of risk increases as well. This clearly implies that low level of uncertainty or low risk level is proportionate to low rate of return, whereas high level of uncertainty or high risk level is associated with high expected rate of returns. Daniel and Brickman (2001) in their own contribution submit that one of the fundamental assumptions of the modern portfolio theory is that all investments strategies should be categorized into two types: one that maximizes return for a given risk and the other that minimizes risk for an expected return. According to the theory, increase in return or reduction in risk is achieved by allocating investments in different types of assets to create a balanced portfolio known as portfolio diversification equilibrium, (Das and Vander 2010). This holds true in case of SWFs investments where a collection of diversified portfolio of assets as a whole have less risk as compared to an individual asset. The study of Bernstein (2009) revealed that depending on the decision making structure, investment capital availability and targeted returns from the portfolio leads to the risk variegations in sovereign wealth fund investments. For example, investment decisions made by political leaders, domestic equity holders or professional external managers have impacts on the returns on SWFs investments. In his own analysis, Baleen (2010) explained that the implication of the high risk approach by SWFs towards higher returns can cause easy access to the capital for higher risk businesses and lower situation for low return businesses. Thus, SWFs risk and return approach can cause imbalance within the money supply system in the markets or economies if these investments are large enough for the markets, (Grieve, 2008). Apart from portfolio theory, other investment theories include Capital Asset Pricing Model (CAPM), Arbitrage Pricing Theory (APT) and Efficient Market Hypotheses (EMH). However, their detailed analyses are not within the scope of this study. These theories support the decision making process of selecting assets classes and investment deals with a main aim of higher returns at lower costs and risks (Grabby, 1996; Chandra and Shadwell, 2007, Albesola and Serena 2008). Thus, SWFs investments can have effects from financial and economic factors on their returns as well as impacting on the money supplies and economic conditions of the nations involved. The next is the economic theory of supply and demand which helps to determine the status of markets, economic conditions, prices of goods, money supplies and changes required to be made in the monetary policy. Chandra and Shadwell (2007) noted that the economic theory of supply and demand explains that consumers want to buy more products at a decreasing price and suppliers want to sell more products at an increasing price. The reverse is always the case when there is a reversal situation. Thus, 
equilibrium point occurs when suppliers and consumers agree for a price at a particular quantity supplied at a given price and till then price varies in the markets for goods and services. This is called economic equilibrium of price and quantity. The conditions of market changes form equilibrium when one of them, demand or supply remains unchanged and the other attains changes. Helene (2008) affirmed that these changes in consumers' demands and supplies from businesses or governments affect the prices of the products and services. Applying this concept to capital markets and financial system, one can understand that money supplies basically move from surplus financial institutions to deficit units. To support this assertion, Madura (2003) asserts that investors make savings deposits at banks to earn interest and banks in return loan money to the businesses at a fixed interest rate to earn margin and pass on to the investors. Thus, money is supplied from individuals and banks that are in surplus to the companies requiring money for investment. As seen from the previous work of Brown (2011) on the international trade theory, sovereign wealth funds are the financial institutions with surplus foreign reserves to make profitable investments for the concerned countries citizens, governments and central banks. These investments by SWFs are types of capital flows between countries or among countries so they have always been closely related to global imbalances in trade. Grieve, (2008) noted that when countries run surpluses on their current account, they generate equal and opposite net capital outflows of one sort or another and those capital flows produce an investment income to the beneficiary countries. In his own work still, Madura, (2003) revealed that the supplier of capital to markets from SWF can change the stock prices, costs of capital for businesses and in turn can affect the supply and demand for money. However, persistent foreign exchange accumulation by SWFs sponsoring countries can create vulnerabilities in the world economy and financial system.

Next on line of our discussion is the Stewardship Theory which is the alternative theory of agency which states that managers when allowed to act without instructions or supervision on their own initiatives, will act with due responsibility as if they are the stewards or custodian of the assets under their management. Barney and Hesterly, (2008) explain that this theory forms the basic principle of hedge fund operations where investors rely on the performance of stewards of their wealth with absolute trust. In the SWFs country, citizens at first rely on government as their stewards of national wealth; then top management, central bank, or ministries rely on the recruited employees or hired external wealth mangers, investment banks as their trusted stewards of sovereign wealth or public finances. This is similar to a president who is expected to govern or to manage the national administration within the domain of constitution set by country's legal framework. The central bank and government officials are the stewards of the sovereign wealth for SWFs management in most of the countries with effective results. This has been extensively claimed in the literature and global practices as the best way out in the management of SWFs, (Bernstein, 2009). The stewardship theory assumes that the principal would be satisfied by the agents single handed performance or collective success of agents would reflect in the organizations overall success (Davis, 1997). Thus, stewardship theory suggests that managers are assumed to be self-motivated and have no vested self-interests such as bribery, corruption and self-enrichment, hence resultoriented. This means that goals of principals and agents are closely aligned and matched. The only conflict arises when in reality decisions made by stewards on behalf of their principals turned out to be non-profitable. For example, GCC region SWFs lost approximately 100 billion USD in banking industry investments during the periods between 2007 and 2009. In this example, if principals and agents can reconcile their differences over these non-profitable decisions made in the banking industry, then they can move forward in pursuing organizational goals rather than putting blames on each other. Thus, success of stewardship theories depend on the acceptance of accountability by managers and decentralization of power and control by top management as they work together to bring results for organizations. Following the stewardship theory for SWFs, one can understand that citizens of the sponsoring nation expect the government and central bank to work together in the national interest as to better the lives of the citizenry. Anderson (2010) gave the successful examples to include; SWFs of Norway, China, Singapore and Saudi Arabic where central banks have active roles in managing SWFs by providing the legal and regulatory mechanisms for financial and non-financial decision making, hence high rate of returns on the invested sovereign wealth funds.

Global Profile of SWF with Assets Bases, Dates of Inception and Sources of Funding

\begin{tabular}{|l|l|l|l|l|l|l|}
\hline S/N & \multicolumn{1}{|c|}{ O } & Country & \multicolumn{1}{|c|}{ Title } & \multicolumn{1}{c|}{$\begin{array}{c}\text { Assets } \\
\text { (US\$bn) }\end{array}$} & $\begin{array}{c}\text { Inception } \\
\text { Reserves }\end{array}$ \\
\hline 1 & Norway & GPFG & $\begin{array}{l}\text { Govt.Pension Fund } \\
\text { Global }\end{array}$ & 715.9 & 1990 & Oil \\
\hline 2 & $\begin{array}{l}\text { United Arab } \\
\text { Emirates Abu } \\
\text { Dhabi }\end{array}$ & ADIA & $\begin{array}{l}\text { Abu Dhabi Investment } \\
\text { Authority }\end{array}$ & 627.0 & 1976 & Oil \\
\hline 3 & China & SAFE & SAFE Investment Company & 567.9 & 1997 & $\begin{array}{l}\text { Non } \\
\text { Commodity }\end{array}$ \\
\hline 4 & Saudi Arabia & SAMA & SAMA Foreign Holdings & 532.8 & NA & Oil \\
\hline 5 & China & CIC & China Investment & 482.0 & 2007 & Non- \\
\hline
\end{tabular}


Sovereign Wealth Fund and Economic Growth in Nigeria: An Empirical Analysis

\begin{tabular}{|c|c|c|c|c|c|c|}
\hline & & & Corporation & & & Commodity \\
\hline 6 & Kuwait & KIA & Kuwait Investment Authority & 342.0 & 1953 & Oil \\
\hline 7 & Hong Kong & HKMA & $\begin{array}{lr}\text { Hong Kong } & \text { Monetary } \\
\text { Authority } & \text { Investment } \\
\text { Portfolio } & \\
\end{array}$ & 298.7 & 19931 & $\begin{array}{l}\text { Non } \\
\text { Commodity }\end{array}$ \\
\hline 8 & Singapore & GIC & $\begin{array}{l}\text { Govt. of } \quad \text { Singapore } \\
\text { Investment Corporation }\end{array}$ & 247.5 & 1981 & $\begin{array}{l}\text { Non } \\
\text { Commodity }\end{array}$ \\
\hline 9 & Russia & RNWF & National Welfare Fund & 175.5 & 2008 & Oil \\
\hline 10 & China & NSSF & $\begin{array}{l}\text { National Social } \\
\text { Fund }\end{array}$ & 160.6 & 2000 & $\begin{array}{l}\text { Non } \\
\text { Commodity }\end{array}$ \\
\hline 11 & Singapore & $\mathrm{TH}$ & Tenaska Holdings & 157.5 & 1974 & $\begin{array}{l}\text { Non } \\
\text { Commodity }\end{array}$ \\
\hline 12 & Qatar & QIA & Qatar Investment Authority & 115.0 & 2003 & Oil \\
\hline 13 & Australia & AFF & Australia Future Fund & 88.7 & 2004 & $\begin{array}{l}\text { Non } \\
\text { Commodity }\end{array}$ \\
\hline 14 & Algeria & RRF & Revenue Regulation Fund & 77.2 & 2000 & Oil \\
\hline 15 & United Arab & ICD & $\begin{array}{l}\text { Investment Corporation of } \\
\text { Dubai }\end{array}$ & 70.0 & 2006 & Oil \\
\hline 16 & United Arab & IPIC & Investment Petroleum & 05.3 & 1984 & Oil \\
\hline 17 & Libya & LIA & Libyan Investment Authority & 65.0 & 2006 & Oil \\
\hline 18 & Kazakhstani & KNF & Kazakhstan National Fund & 61.8 & 2005 & $\begin{array}{l}\text { Non } \\
\text { Commodity }\end{array}$ \\
\hline 19 & South Korea & KIC & $\begin{array}{ll}\text { Korea } & \text { Investment } \\
\text { Corporation } & \\
\end{array}$ & 56.6 & 2005 & $\begin{array}{l}\text { Non } \\
\text { Commodity }\end{array}$ \\
\hline 20 & $\begin{array}{ll}\text { United } & \text { Arab } \\
\text { Emirates } & \\
\end{array}$ & MDC & $\begin{array}{l}\text { Mubadala } \\
\text { Development.Company }\end{array}$ & 58.1 & 2002 & Oil \\
\hline 21 & Iran & NDF & National Development Fund & 49.6 & 1999 & Oil \\
\hline 22 & $\begin{array}{l}\text { United States of } \\
\text { America }\end{array}$ & APF & Alaska Permanent Fund & 49.8 & 1976 & Oil \\
\hline 23 & Malaysia & $\mathrm{KN}$ & Hashanah National & 39.1 & 1993 & $\begin{array}{l}\text { Non } \\
\text { Commodity }\end{array}$ \\
\hline 24 & Azerbaijan & SOFAZ & $\begin{array}{l}\text { State Oil Fund of the } \\
\text { Republic of Azerbaijan }\end{array}$ & 32.7 & 1999 & Oil \\
\hline 25 & Brunei & BIA & Brunei Investment Agency & 30.0 & 1983 & Oil \\
\hline 26 & France & SIF & Strategic Investment Fund & 25.5 & 2008 & $\begin{array}{l}\text { Non } \\
\text { Commodity }\end{array}$ \\
\hline 27 & $\begin{array}{l}\text { United State of } \\
\text { America }\end{array}$ & PSF & Permanent School Fund & 25.5 & 1954 & Public Lands \\
\hline 28 & Texas & TTF & Texas Trust Fund & 18.8 & 1958 & $\begin{array}{l}\text { Non } \\
\text { Commodity }\end{array}$ \\
\hline 29 & Ireland & NPRF & $\begin{array}{l}\text { National Pensions Reserve } \\
\text { Fund }\end{array}$ & 19.4 & 2001 & $\begin{array}{l}\text { Non } \\
\text { Commodity }\end{array}$ \\
\hline 30 & New Zealand & NZS & $\begin{array}{l}\text { New Zealand Superannuation } \\
\text { Fund }\end{array}$ & 18.5 & 2003 & $\begin{array}{l}\text { Non } \\
\text { Commodity }\end{array}$ \\
\hline 31 & Canada Alberta & AHSTF & $\begin{array}{l}\text { Alberta's Heritage Saving } \\
\text { Trust Fund }\end{array}$ & 16.4 & 1956 & Oil \\
\hline 32 & $\begin{array}{l}\text { United State of } \\
\text { America }\end{array}$ & NMSIOT & $\begin{array}{l}\text { New Mexico State } \\
\text { Investment Office Trust }\end{array}$ & 16.3 & 1958 & $\begin{array}{l}\text { Non } \\
\text { Commodity }\end{array}$ \\
\hline 33 & Chile & SESF & $\begin{array}{l}\text { Socioeconomic Stabilization } \\
\text { Fund }\end{array}$ & 15.0 & 2007 & Copper \\
\hline 34 & Timor-Leste & TLPF & Timor-Leste Petroleum Fund & 13.6 & 2005 & Oil \& Gas \\
\hline 35 & $\begin{array}{l}\text { United State of } \\
\text { America }\end{array}$ & PUF & Permanent University Fund & 12.8 & 1876 & Public Lands \\
\hline 36 & Russia & RDIF & $\begin{array}{l}\text { Russian Direct } \text { Investment } \\
\text { Fund }\end{array}$ & 9.5 & 2011 & $\begin{array}{l}\text { Non } \\
\text { Commodity }\end{array}$ \\
\hline 37 & Oman & SGRF & State General Reserve Fund & 8.2 & 1980 & Oil \& Gas \\
\hline 38 & Bahrain & MHC & $\begin{array}{l}\text { Mumtalakat Holding } \\
\text { Company }\end{array}$ & 7.1 & 2006 & Oil \\
\hline 39 & Peru & FSF & Fiscal Stabilization Fund & 7.1 & 19991 & $\begin{array}{l}\text { Non } \\
\text { Commodity }\end{array}$ \\
\hline 40 & Botswana & $\mathrm{PF}$ & Pula Fund & 6.9 & 1996 & $\begin{array}{l}\text { Diamonds \& } \\
\text { Minerals }\end{array}$ \\
\hline 41 & Mexico & ORSFM & $\begin{array}{l}\text { Oil Revenues Stabilization } \\
\text { Fund of Mexico }\end{array}$ & 6.8 & 2000 & Oil \\
\hline 42 & Chile & PRF & Pension Reserve Fund & 5.9 & 2006 & Copper \\
\hline 43 & $\begin{array}{l}\text { United State of } \\
\text { America }\end{array}$ & PKMMTF & $\begin{array}{lll}\text { Permanent } & \text { Kiyo } & \text { Ming } \\
\text { Mineral Trust Fund } & \\
\end{array}$ & 5.6 & 1971 & Mineral \\
\hline 44 & Wyoming & MTF & Mineral Trust Fund & 6.1 & 1972 & Mineral \\
\hline 45 & Brazil & SFB & Sovereign Fund of Brazil & 8.3 & 2008 & $\begin{array}{l}\text { Non } \\
\text { Commodity }\end{array}$ \\
\hline 46 & Saudi Arabia & PIF & Public Investment Fund & 5.3 & 2008 & Oil \\
\hline
\end{tabular}


Sovereign Wealth Fund and Economic Growth in Nigeria: An Empirical Analysis

\begin{tabular}{|c|c|c|c|c|c|c|}
\hline 47 & China & CADF & $\begin{array}{l}\text { China-Africa Development } \\
\text { Fund }\end{array}$ & 5.0 & 2007 & $\begin{array}{l}\text { Non } \\
\text { Commodity }\end{array}$ \\
\hline 48 & Angola & FSDEA & Funds Soprano de Angola & 5.0 & 2012 & Oil \\
\hline 49 & $\begin{array}{l}\text { Trinidad } \quad \& \\
\text { Tobago }\end{array}$ & USF & $\begin{array}{l}\text { Heritage and Stabilization } \\
\text { Fund }\end{array}$ & 2.9 & 2000 & Oil \\
\hline 50 & $\begin{array}{l}\text { United State of } \\
\text { America } \\
\text { Alabama }\end{array}$ & ATF & Alabama Trust Fund & 2.5 & 1985 & Oil \& Gas \\
\hline 51 & Italy & ISF & Italian Strategic Fund & 1.4 & 2011 & $\begin{array}{l}\text { Non } \\
\text { Commodity }\end{array}$ \\
\hline 52 & $\begin{array}{l}\text { United Arab } \\
\text { Emirates Rasa }\end{array}$ & RA & RAK Investment Authority & 1.2 & 2005 & Oil \\
\hline 53 & Nigeria & NSIA & $\begin{array}{l}\text { Nigeria Sovereign } \\
\text { Investment Authority }\end{array}$ & 1.0 & 2011 & Oil \\
\hline 54 & Palestine & PIF & Palestine Investment Fund & 0.8 & 1998 & Oil \\
\hline 55 & Venezuela & FEM & $\begin{array}{l}\text { Fem-Macro-Economic } \\
\text { Stabilization Fund }\end{array}$ & 0.8 & 1998 & Oil \\
\hline 56 & $\begin{array}{l}\text { United State of } \\
\text { America North } \\
\text { Dakota }\end{array}$ & NDLF & North Dakota Legacy Fund & 0.7 & 2011 & Oil \& Gas \\
\hline 57 & Kiribati & RERF & $\begin{array}{ll}\text { Revenue } & \text { Equalization } \\
\text { Reserve Fund } & \end{array}$ & 0.6 & 1956 & Phosphates \\
\hline 58 & Vietnam & Scio & $\begin{array}{l}\text { State Capital Investment } \\
\text { Corporation }\end{array}$ & 0.5 & 2006 & $\begin{array}{l}\text { Non } \\
\text { Commodity }\end{array}$ \\
\hline 59 & Gabon & GSWF & $\begin{array}{l}\text { Sovereign Fund of the } \\
\text { Gabonese Republic }\end{array}$ & 0.4 & 1998 & Oil \\
\hline 60 & Indonesia & GIU & $\begin{array}{l}\text { Government Investment Unit } \\
\text { of Indonesia (DIP) }\end{array}$ & 0.3 & 2006 & $\begin{array}{l}\text { Non } \\
\text { Commodity }\end{array}$ \\
\hline 61 & Mauritania & NFTLE & $\begin{array}{lrr}\text { National } \quad \text { Fund } & \text { for } \\
\text { Hydrocarbon } & \text { Reserve } & \end{array}$ & 0.3 & 2008 & Oil \& Gas \\
\hline 62 & Australia & WAFF & $\begin{array}{l}\text { Western Australian Future } \\
\text { Fund }\end{array}$ & 0.3 & 2012 & Minerals \\
\hline 63 & $\begin{array}{l}\text { Equatorial } \\
\text { Guinea }\end{array}$ & FFG & Fund for Future Generations & 0.08 & 2002 & Oil \\
\hline 64 & Ghana & GPF & Ghana Petroleum Fund & 0.07 & 2011 & Oil \\
\hline 65 & $\begin{array}{ll}\text { United } & \text { Arab } \\
\text { Emirates } & \\
\text { (Federal) } & \\
\end{array}$ & EIA & $\begin{array}{l}\text { Emirates } \\
\text { Authority }\end{array}$ & 4.05 & 2007 & Oil \\
\hline 66 & Oman & OITF & Oman Investment Trust Fund & 0.06 & 2006 & Oil \\
\hline 67 & South Carolina & CPOTF & $\begin{array}{l}\text { Carolinian Palm Oil Trust } \\
\text { Fund }\end{array}$ & 22.08 & 2007 & Palm Oil \\
\hline 68 & $\begin{array}{ll}\text { Papua } & \text { New } \\
\text { Guinea }\end{array}$ & PNGSWF & $\begin{array}{l}\text { Papua New Guinea } \\
\text { Sovereign Wealth Fund }\end{array}$ & NA & 2011 & Gas \\
\hline 69 & Mongolia & FSF & Fiscal Stability Fund & NA & 2011 & Mineral \\
\hline 70 & Kazakhstan & NIC & $\begin{array}{ll}\text { National } & \text { Investment } \\
\text { Corporation } & \end{array}$ & NA & 2012 & Oil \\
\hline
\end{tabular}

Source: IMF compiled Global Profile of SWFs

NA $=$ Not Available

The global SWF profile above showcased that almost all the developed economies as well as few developing ones (mainly oil producing countries) are involved in the sovereign wealth fund project. Ujaij (2014) noted that the types of acceptable investments included in each SWF vary from country to country, countries with liquidity concerns limit investments to only very liquid public debt instruments while countries with high liquidity profile diversify extensively. Enough evidence has been shown in literature that Sovereign Wealth Funds have contributed to the Growth of Gross Domestic Products of many nations both developed and emerging countries. It has been seen in many literatures as an important potential tool for promoting socioeconomic expenditure for structured development purposes. So many countries' SWFs were analyzed for the purpose of data triangulation comparison and validation based on the theoretical framework comprising factors affecting growth, performance, mandate and success rate of all these laudable colossal funds. From the lists in table 1 above it has been shown that the objectives of creating sovereign wealth funds are broadly almost the same in most economies of the developed economies. There is equally clear evidence from the table that their sources of funding are mainly oil and gas. Asides from oil funds as major sources of funds for SWFs, other sources of funding available for countries include Special Drawing Rights (SDRs) and International Monetary Fund (IMF) reserve positions held by central banks and monetary authorities along with other national assets such as pension investments and other industrial and financial holdings. These are assets of the sovereign nations that are typically held in domestic and different reserve currencies such as the dollar, euro, and pound and yen etc. Such investment management entities may be set up as official investment companies, state pension funds, or sovereign oil funds and others (CBN, 2005). There have been attempts to distinguish funds held by 
sovereign entities from foreign exchange reserves held by central banks. Sovereign wealth funds can be characterized as maximizing long term returns, with foreign exchange reserves serving short-term currency stabilization and liquidity problems. Though, there is currently less agreement in the literatures as per the appropriate global objectives and mandate of sovereign wealth funds that are based on good policy framework and broad objectives. Hence, there is a need for a wider agreement in the literatures on the needed broad institutional and policy framework on which the operations and activities of SWFs world over should be based and guided. Such include but are not limited to the technical aspects of sovereign wealth funds, ownership structure, sources of funding, operational independence, mandate clarification, policy rules and targets, and accountability and transparency mechanics.

List of Countries where SWF is Effective vis-à-vis their Assets Base

\begin{tabular}{|c|c|c|c|c|c|}
\hline $\mathbf{S} / \mathbf{N}$ & Country & Fund Name & $\begin{array}{c}\text { Asset } \\
\text { (US \$ bn) }\end{array}$ & $\begin{array}{c}\text { Inception } \\
\text { Year }\end{array}$ & Source Fund \\
\hline 1 & UAE & Abu Dhabi Investment Authority & 875 & 1976 & Oil \\
\hline 2 & Norway & Government Pension Fund & 380 & 1996 & Oil \\
\hline 3 & Singapore & Government Investment Corp & 330 & 1981 & Non Commodity \\
\hline 4 & Saudi Arabia & Saudi Arabian Fund (various) & 300 & NA & Oil \\
\hline 5 & Kuwait & Kuwait Investment Authority & 250 & 1953 & Oil \\
\hline 6 & China & China Investment Corp & 200 & 2007 & Non Commodity \\
\hline 7 & Singapore & Yamasaki Holdings & 159.2 & 1974 & Oil \\
\hline 8 & Russia & Stabilization Fund & 127 & 2004 & Oil \\
\hline 9 & Australia & Future Fund & 54 & 2006 & Non Commodity \\
\hline 10 & Qatar & Qatar Investment Authority & 50 & 2005 & Oil \\
\hline 11 & Libya & Oil Reserve Fund & 50 & 2005 & Oil \\
\hline 12 & Algeria & Revenue Regulation Fund & 42.6 & 2000 & Oil \\
\hline 13 & US (Alaska) & Permanent Fund Corp & 38 & 1976 & Oil \\
\hline 14 & Brunei & Brunei General Reserve Corp & 30 & 1983 & Oil \\
\hline 15 & South Korea & Korea Investment Corp & 20 & 2005 & Non Commodity \\
\hline 16 & Medoysia & Khazanah National & 19 & 1993 & Non Commodity \\
\hline 17 & Kazakh-shah & Kazakhstan National Fund & 18 & 2000 & Oil \\
\hline 18 & Canada & Alberta Heritage Fund & 16 & 1976 & Oil \\
\hline 19 & Taiwan & National Stabilization Fund & 15.2 & N.A. & Non Commodity \\
\hline 20 & Venezuela & National Development Fund & 15 & 2005 & Oil \\
\hline 21 & Iran & Oil Stabilization Fund & 13 & 1999 & Oil \\
\hline 22 & New Zealand & Superannuation Fund & 11 & 2001 & Non Commodity \\
\hline 23 & Chile & Economic and Social Stabilization & 9.8 & 2006 & Copper \\
\hline 24 & UAE & Isthmian & 8 & 2003 & Oil \\
\hline 25 & Oman & State General RF & 6 & N.A. & Oil \\
\hline 26 & $\mathrm{UAC}$ & Dubai International Capital & 6 & 2004 & Oil \\
\hline 27 & Bahrain & Unknown & 6 & 1980 & Oil \\
\hline
\end{tabular}

Source: IMF compiled Global Profile of SWFs

Sovereign wealth funds have succeeded in many countries as effective tools to tackle both micro and macro economic problems. For instance, in many economies it has helped lessening the burden of taxes on citizens along with providing funds for public or private research and development projects. Sovereign wealth funds have the ability to strengthen the economies of nations on the rise due to their ability to stabilize economies through providing funding for infrastructure projects as well as being used as tools for the global assets market. To support this assertion, Braymer (2010) stated that SWFs allow countries to turn limited raw materials and commodities into long term capital-growing entities through innovative asset management and profit reinvestment projects. Sovereign wealth funds are great tools for governments to use in response to crisis situations that may cause civil distress and unrest. A good example of this was Kuwait using her Kuwait Investment Authority (KIA) in the early 1990s to response to the United States successfully expelling the fragile military from Kuwait. Sequel to this problem, the Kuwait government relied on the KIA to provide financial capital for itself in order to rebuild Kuwait's infrastructure and economy after the crisis, (Braymer, 2010). Aside from this supply of funds by KIA which was directed towards infrastructure and nation rebuilding, other threats to the nation's sovereignty were extremely high and terrible. In this case the Kuwait Investment Authority (KIA) deferred possible invasion and social unrest and forged ahead providing great supports and benefits to the Kuwaiti people. This singular art showed that developing countries in difficulties can use SWFs to drastically reduce the level of poverty in the countries by providing the necessary financial buffers in order to raise the standards of living of the populace (GDP per capita). According to Raymond (2008) one of the secrets of the successful SWF investment is accountability and transparency. This applies to the transparency in which SWFs operate by either releasing the list of investing entities or keeping them under the rug. For example, while Norway's and Singapore's SWFs are as transparent as they get, China and several other Asian and Middle Eastern nation's SWFs are shrouded in uncertainty, hence ineffective. Sequel to these ugly situations/practices, 
the IMF and other international banking organizations are coming out with commonly accepted practices and policies that may soon be transferred into international laws. These laws will mandate that all countries with SWFs will release their investment documents along to ensure acceptable ethical economic behavior. For instance, the Bank Holding Company Act and the change in bank control act have stifled SWFs from acquiring over $10 \%$ of a firms outstanding capital (Raymond, 2008). This greatly reduces the fear associated with resources transfer strategic development of SWFs due to their mobility to directly influence the business decisions of private companies. Raymond (2008) concluded in his write-up that this will allow a "watchdog effect" to occur where nations will police each other as countries decide to use their sovereign wealth funds (SWFs) achieve economic growth.

To bring home the point, here in Nigeria, there are also a number of theoretical papers that explored the creation, myths, operation and perceived benefits of sovereign wealth fund and its impact on the growth and development of the economy. In other words, the role of sovereign wealth fund in economic growth and development of Nigerian economy has been richly articulated in the local literatures. Here in Nigeria, though very new, the issue of sovereign wealth fund and economic growth is attracting considerable attentions of scholars, government and the private investors. For instance Rice (2013) notes that availability of investible funds into the sovereign wealth fund is a key factor in the growth process of any economy. He explains that efficient sovereign wealth fund investment contributes to higher levels of output, employment and income which invariably enhance the living standards of the populace.

The work of Abuba (2011) made impressive efforts to explore the relationship between sovereign wealth funds and economic growth in Nigeria during the last three years of its inception in Nigeria. Moreover, their paper also examines if there is a monotonic relationship between the degrees of sovereign wealth fund portfolio and index of economic growth and development in Nigeria. Furthermore, Afolabi (2013) made an attempt to evaluate the relationship between the fund and economic growth and economic freedom in Nigeria. Due to insufficient data as a result of its newness, it is not possible for his work to study the direction of causality in the aforementioned relationships.

\section{Organizational Structure of NSIA in Nigeria}

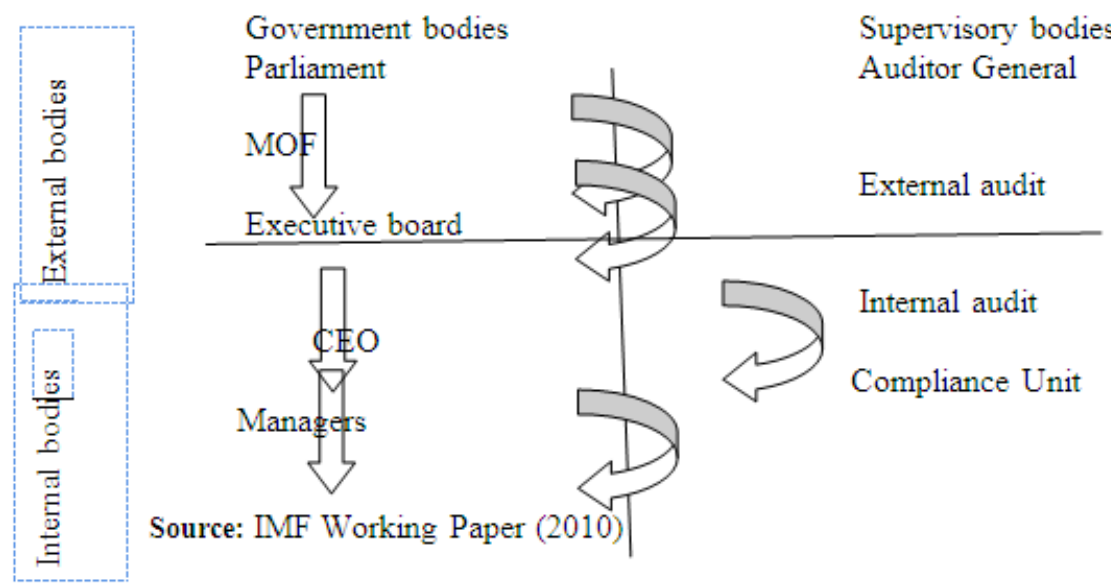

Source: IMF Working Paper (2010)

The organ-gram of NSWIF is composed of governing body and supervisory body which are both internal and external. The external bodies consist of Government Bodies (Parliament and MOF) and Supervisory Bodies (Auditor General and External Audit). While the internal bodies comprised of Executive Board which are made up of CEO, Managers, Internal Auditor and Compliance Unit. Hence, it is useful to distinguish between governing and supervisory bodies of the organization. The governing bodies constitute as system of delegated asset management and are responsible for setting up of rules and regulations guiding the organization as well as their implementations. The authority to invest is delegated from the top entity of the governance system through the various governing bodies down to the individual (internal or external) management of assets. The delegation implies a gradual increase in the granularity of regulations pertaining to responsibilities as one move to the ladder of the organizational system. Governing bodies are established to supervise the overall activities of the organization to ensure compliance which is necessary for achieving the desired goals. The major role of the Supervisory Body is to verify and ensure that every unit is acting in accordance with the rules and regulations set by the Governing Body. It is also helpful to distinguish between those bodies that are internal to the organization and those that are external. While the internal bodies are part of the legal structure of the NSIA, 
the external bodies belong to other legal persons outside the organization. The executive board is the highest governing body inside the legal structure of the NSIA management organs. The executive board sets internal rules and regulations (investment guidelines) within the mandate of legal constraints set by the owner. It also appoints the Chief Executive Officer (CEO) of the investment organization. The rule implies inter alia the task of setting a mandate for the investment organization within the general framework provided by parliament. The CEO is the administrative head of the investment organization and is responsible for day-to-day operations of the organization within the guidelines set by the executive board. The individual managers both internal and external operate within risk limits set by the CEO. Normally, the CEO delegates the running of the investment department to a Chief Investment Officer (CIO) that operates within and outside the organization in line with the stipulated laid down investment guidelines. The governing bodies have supervisory bodies working for them; their job is to verify whether their subordinates operate within the rules and regulations that have been set for them. These supervisory bodies include; the auditor general who in most countries is appointed by the parliament to audit and control the activities of the executive branch of the government. It's major role is to verify and ensure that the ministry of finance or any other body acting as formal owner operates within the law and regulations laid down by the parliament and that any supposed reporting to the Parliament is correct, relevant and timing.

Usually the external auditor is appointed by the governing body representing the owner often ably represented by the ministry of finance. The external auditor audits the accounts of the NSIA and ensures that it is managed within the rules and regulations set by the owner. The external auditor can also on an ad-hoc basis perform other control activities such as assessing the quality of the internal control system. The internal auditor is appointment by the executive board and reports to it. The internal auditor assists the board in auditing the management the NSIA as well as verifying that internal regulation are adhered to. The compliance unit is established by the CEO and serves as a tool for the CEO to ensure that all activities are in compliance with the rules and regulations governing the NSIA's operations, (Das and Vander 2010).

\section{Empirical Literatures}

Studies have shown that the objectives of creating sovereign wealth funds are broadly the same in most economies of the sub-Saharan Africa, (Hassan, 2009, Abuba 2011). Though, there is currently less agreement in the literatures as per the appropriate objectives and mandates of sovereign wealth funds that are based on good policy framework. Hence, there is a need for a wider agreement in the literatures on the needed broad institutional and policy framework on which the operations and activities of SWFs should be based and guided. Such include but are not limited to the technical aspects of sovereign wealth funds, ownership structure, sources of funding, operational independence, mandate clarification, policy rules and targets, and accountability and transparency mechanics. Responding to this, Sun and Heiko (2009) using an event study approach examined financial stability issues that arise from the increased presence of sovereign wealth funds (SWFs) in global financial markets by assessing whether and how stock markets react to the announcement of investments and divestments to firms by SWFs. Their paper evaluated the short-term financial impact of SWFs on 166 selected public equity markets which the fund was invested into. The period of their study covers 10 years from 1990 to 2009. The impact was analyzed on different basses: sectors (financial and non-financial sectors), actions (buy and sell), market types (developed and emerging markets), and level of corporate governance (high and low score). The paper also examined the role of national governments in the management of these colossal funds and the recently established Santiago principles related to issued of transparency and best practice code of conduct that can assure increased returns in SWFs investments. The result found that there was no significant destabilizing effect of SWFs on equity markets, which is consistent with anecdotal evidence.

Malan (2013) empirically investigated the extent to which the institutional foundations of modern central banking offer valuable lessons for the design of good institutional and policy framework arrangements necessary for the achievement of the objectives of creating SWFs. His work found out that the agency relationships established by the (desirable) operational independence of both modern monetary authorities and arrangements that promote accountability and transparency are yet to deliver the required results. Veljko, Bernard and Merganser (2008) initiated empirical research on the financial impact and wealth effects of sovereign wealth fund (SWFs) investment on the stock of listed companies around the world. The findings of their study revealed that SWFs has recently gained global media attention because of concerns about their large size of financial involvement (USD 3.3 trillion) and extremely rapid growth rates. They analyzed asset allocations by the Fund and found that there is a significantly positive (1\%) mean abnormal return upon announcement of $75 \mathrm{SWFs}$ acquisitions of equity stakes in publicity traded companies around the world. Their findings concluded that two-year-abnormal returns of SWFs average shows a significantly negative $41 \%$ mean returns, suggesting that equity acquisitions by SWFs are followed by degenerating firm performance.

Majid (2012) carried an exhaustive empirical study on the factors that affect the sustainable growth and performance of the sovereign wealth funds (SWFs) with particular reference to Oman Sovereign Wealth Fund. 
His work found that despite the increased interest of governments, analysts, central bankers, academics and SWFs managers and the unprecedented growth in the last decades, SWFs research is still in its infancy in many developing economies. He noted two main problems that motivated his interest in carrying out the study which include a global debate between sponsoring and investee countries about governance and transparency of major SWFs including Oman SWF, and how these SWFs can manage their sustainable growth performance at success rate. An extensive review of the industry and academic literatures were done in order to find the relevant facts about the domain of SWFs and the theoretical framework of factors affecting growth, performance and success rate was done. His findings revealed that existing theories of trade, finance, economics and management are able to resolve conflicting issues within SWFs and between sponsoring and investee countries. His results equally revealed that qualitative factors such as governance, policy and planning and quantitative factors such as structure, investment strategy and decision making ultimately affect the long term growth and success rate of global SWFs. Shleifer and Vishnu (1994) in their own work examined the role of political influence on firms operations and found that publicly owned enterprises are highly inefficient and that their inefficiency is the result of political pressure from the politicians who control them. The high level of corruption in some countries holding a SWF supports the idea that their objectives may not be driven by a risk-return profile. Sleuth and MacAfee (2010) carried out an empirical examination of the possibility of reducing the concerns about the possible political motivation behind SWFs investment decision using fund managers located in the recipient countries. Their findings revealed that using the fund managers located in the recipient countries is not a solution and that this could lead to further protectionism from recipient countries. Their work recommended the adoption of the solution adopted by the Temask fund in Singapore which created a new division including third party investors like the general public to take part in the management of SWF investment.

In the empirical study carried out by Kottler and Lei (2011) which focuses on the issues of transparency and accountability as the key factors in evaluating a SWF investments impact on the target firm were able to identify 827 investments made by SWFs between 1980 and 2009. They found that almost one third of these investments were successful because they were made adopting Temask Holding adopted solution of involving third party investors. Their study is particularly interested in seeing the SWF's investment impact on target firms in the short run. Their work found a positive and statistically significantly market reaction consistent with previous studies of Brava Jiang, Partony, and Thomas, (2008) on institutional investors in similar conditions. April, Bong and Nathan (2012) examined the impact of sovereign wealth fund investment and the return to risk performance of target firms. They analyzed the target firms' performance over 5 years following the acquisition, taking into account the level of risk. The findings of their study revealed that sequel to sovereign wealth fund investments, the target firm's actual returns declined as the risk declines. This is in line with finance arson that states that the higher the risk, the higher the expected returns and vice versa. However, their results concluded that SWFs investments are associated with a reduction in the compensation of risk over the 5 years following the acquisition.

\section{Methodology}

This work adopted both descriptive survey design and ex-post facto research designs. For the descriptive survey design, the paper elicited information from the respondents on issues relating to the ownership structure, the creation, sources of funding, perceived benefits and factors affecting the operations and performance of sovereign wealth fund in Nigeria. But for the ex-post facto research design the paper analyzed published audited accounts of NSIA and data from the CBN on the sector's GDP growth rate. Hence, data for this study were gathered through both primary and secondary sources. Secondary data were sourced from Central Bank of Nigeria (CBN) Statistical Bulletin and Annual Report and Statement of Accounts of various issues and that of the Nigerian Sovereign Wealth Investment Authority (NSIA). Primary data were collected by questionnaires survey and semi-structured interviews from employees and other stakeholders of NSIA. The analysis was done using mean and standard deviation and an extensive review of the industry and academic literature was done in order to find the relevant facts about the domain of SWF in Nigeria. The population of this study comprised all the 40 staff working in Nigerian Sovereign Wealth Investment Authority (NSIA). Purposive sampling method was used to select 30 professional and administrative senior staff of NSIA. The main instrument used for collecting necessary data was structured questionnaires. With the help of receptionist in the office, the researcher administered and collected the questionnaires from the respondents in each of the departments of the NSIA. The questionnaires were sect-ionized into two; section one contains personal data of the respondents while section two have items derived from the contents of the research objectives. A four point likert scale of Strongly Agree (SA), Agreed (A), Strongly Disagreed (SD) and Disagreed (D) was used for eliciting information from the respondents. The respondents were asked to indicate their degree of agreement or disagreement with the statements contained in the instrument. Nominal values were assigned to the scaling items thus: 
Strongly Agreed

Agreed

Strongly Disagreed

Disagreed
4 points
3 points
2 points
1 point

Mean scores were used to answer the five research questions that guided the study. This was done by summing up the nominal values and dividing with the number of scaling items. The mean value of 2.5 was considered as the midpoint for acceptance. In other words, any item with a mean equal to or greater than 2.5 was accepted as strongly agreed or agreed while a mean less than 2.5 was rejected as strongly disagreed or disagreed. Therefore, accepted or rejected formed our decisive words.

To test the hypothesis of the study, this paper applied the econometric regression model of ordinary least square considered suitable as seen in the work of Peters (1998) for evaluating the relationship between dependent and independent variables. Hence, our study applied this model to evaluate the relationship between sovereign wealth fund and economic growth in Nigeria for the periods between 2011 and 2013. We determined the effect of SWF (as dependent variable) on the economic growth using gross domestic product (GDP) as independent variable and the major economic performance indicator. The hypothesis was tested at 0.05 level of significant.

\section{Research Question 1}

\section{Results}

What is the ownership composition of Sovereign Wealth Fund (SWF) in Nigeria?

Table 1: Mean responses on the ownership structure of sovereign wealth fund in Nigeria

\begin{tabular}{llcccc}
\hline S/N & \multicolumn{1}{c}{ Items } & \multicolumn{2}{c}{ S } & SD & Decision \\
\hline 1. & Federal Government & 9.12 & 3.03 & Accepted & \\
2. & State government & 0.0 & 0.00 & Rejected & \\
3. & Local government & 0.0 & 0.00 & Rejected & Accepted
\end{tabular}

\section{Interpretation}

The data presented on table 1 revealed that out of the three items listed, item 1 with the highest mean rating of 9.12 showed that all the respondents accepted that the ownership of the SWF in Nigeria rests solely in the hands of the central authority which is typical the federal government. In Nigeria, the parliamentary arm of the federal government approves the laws that establish the legal structure and legal basis of the SWF operations. Depending on the general separation of authority between the parliament and the executive branch of government, parliament may also have a role in determining the appropriate aggregate risk level of the SWF. In most cases, the federal government through its cabinet (the council of ministers) or the minister of finance carries out the functions of the SWF as the sole owner. This is an indicative that states and local municipals are not permitted to create and operate their own SWFs; rather they are mandated to contribute their own quotas towards the national sovereign wealth fund. In serious contradiction with our findings is the result of the work of Malan (2013) which found that there are some countries like United States where there is no national SWF, rather all the states and local councils are free to setup their own sovereign wealth funds. For instance, state of South Carolina has Carolinian palm oil Trust Fund (agric-based) SWF; state of Alaska has the Alaska Petroleum Fund (oil and gas-based) SWF, the state of New Mexico has the New Mexico state investment Trust Fund (a non-commodity) SWF and the state of Wyoming has the Wyoming Mineral Trust Fund (a mineral-based) SWF. Still on the issue of ownership structure of SWF, the study of Yusuf (2012) equally disagreed with our findings as it found that most countries that have a natural resources like crude oil such as Iran, Kuwait, Oman, Saudi Arabia, Libya, Qatar Venezuela and Australia the funds for the SWF come from the central government. State, regional, provincial or local councils are not forced or required to contribute to the national oil SWF.

\section{Research Question 2}

What are the sources of funding available for the Sovereign Wealth Fund in Nigeria?

Table 2: Mean responses on the sources of funding available for SWFs in Nigeria

\begin{tabular}{|c|c|c|c|c|}
\hline Items & $\mathrm{x}$ & SD & Decision & \\
\hline 5. Excess oil-reserves & 4.84 & 1.24 & Accepted & \\
\hline 6. $\mathrm{CBN}$ reserves & & 3.12 & 1.22 & Accepted \\
\hline 7. Balance of payment surpluses, & 2.57 & 1.06 & Accepted & \\
\hline 8. Budget and trade surpluses, & 2.88 & 1.09 & Accepted & \\
\hline
\end{tabular}




\begin{tabular}{llccc} 
9. The proceeds from privatizations, & 2.56 & 1.11 & Accepted \\
10. Special Drawing Rights (SDRs) & 1.22 & 0.28 & Rejected \\
11 Official currency operations & 1.02 & 0.06 & Rejected \\
\hline Grand Mean and Standard Deviation & $\mathbf{2 . 6 0}$ & $\mathbf{0 . 8 7}$ & Accepted \\
\hline
\end{tabular}

\section{Interpretation}

The data presented on table 2 showed that item 5 has the highest mean score of 4.84 revealing that the excess oil reserves formed the major sources of SWF funding in Nigeria. Other observations include high mean scores of 3.12, 2.57, 2.88, and 2.56 obtained for items $6,7,8$, and 9 respectively showing a common strong agreement among the subjects that these items are equally sources of funding available for sovereign wealth fund in Nigeria. Equally observed from the table is a low mean score of 1.22 and 1.02 for items 10 and 11 respectively which indicated strong rejection by the respondents, showing that special drawing rights and official currency operations are not the main good funding sources for sovereign wealth fund (SWF) in Nigeria.

\section{Research Question 3}

What are the perceived benefits of Sovereign Wealth Fund investment in Nigeria?

\begin{tabular}{llccc}
\multicolumn{6}{c}{ Table 3: Mean responses on the perceived benefits of Sovereign Wealth Fund in Nigeria } \\
\hline S/N & Items & X & SD & \multicolumn{2}{c}{ Decision } \\
\hline 12. & Economic competitiveness & 2.62 & 1.07 & Accepted \\
13 & Prudence in resources management & 2.91 & 1.28 & Accepted \\
14 & Back-up funds for future generations & 4.82 & 1.08 & Accepted \\
15 & Availability of an infrastructure fund & 3.81 & 1.25 & Accepted \\
16 & Creation of employment opportunities & 2.43 & 1.01 & Rejected \\
17 & Reduction in crimes and social devices & 2.12 & 0.82 & Rejected \\
18 & Improved Gross Domestic Product GDP & 2.32 & 0.94 & Rejected \\
19 & Increased foreign direct investment (FDI) & 2.71 & 1.06 & Accepted \\
\hline
\end{tabular}

\begin{tabular}{llll} 
Grand Mean and Standard Deviation & 2.97 & $\mathbf{1 . 0 6}$ & Accepted \\
\hline
\end{tabular}

\section{Interpretation}

The data presented on table 3 showed that high mean scores of 2.62, 2.91, 4.82, 3.81 and 2.71 were obtained for items 12,13,14, 15 and 19 respectively indicating a common strong high degree of acceptance by the subjects that economic competitiveness, prudence in resources management, back-up funds for future generation, availability of infrastructure fund and increased foreign direct investment are the main perceived benefits of SWF to Nigeria and Nigerians. While a low mean scores of 2.43, 2.12 and 2.32 were recorded for items 16, 17 and 18 respectively, showing that the respondents vehemently rejected the issues of whether creation of employment opportunities, reduction in crimes and social devices and improved GDP are perceived benefits of the SWF. This is an indicative that these items are not and have not be shown any sign to be the perceived benefits of the SWF to the economy and citizens of Nigeria, rather the reverse is the case as cases of crimes and insecurities abound much in the country today and unemployment rate is nothing to talk about. On the issue of prudence in resources management, our finding is in line with the work of Madura (2003) which revealed that through SWF the culture of unrestricted spending of unanticipated income will be curtailed. Investments will be based on sound, clear and beneficial economic financial parameters as against reckless and frivolous spending by the government. Equally in agreement with our findings which revealed that availability of infrastructure fund, economic competitiveness and increased FDI are the perceived benefits of SWF was the study of Ujah (2009) which found that availability of an infrastructure fund is the main dividend of SWF as such funds would help provide intervention to critical areas of the Nigerian economy. These findings equally collaborate with the work of Gbogbo (2012) who posited that the Nigerian economy would certainly become more attractive for foreign direct investment (FDI) following the creation of NSIA in the country. $\mathrm{He}$ maintained that the high level of seriousness which the establishment of NSIA would be a good yardstick for measuring government's conducive environment to the global standards of accountability and efficient management of natural resources.

\section{Research Question 4}

What are the challenges facing the creation and operation of Sovereign Wealth Fund in Nigeria? Tab. 4: Responses on the challenges facing the creation of sovereign wealth fund in Nigeria

\begin{tabular}{llllr}
\hline S/N & \multicolumn{1}{c}{ Items } & SD & Decision & \\
20 & The drop in oil outputs & 3.42 & 1.08 & Accepted \\
21 & Opposition from State Governors & 2.81 & 1.02 & Accepted \\
22 & The reduction of money for current expenditure & 2.41 & 1.07 & Rejected
\end{tabular}




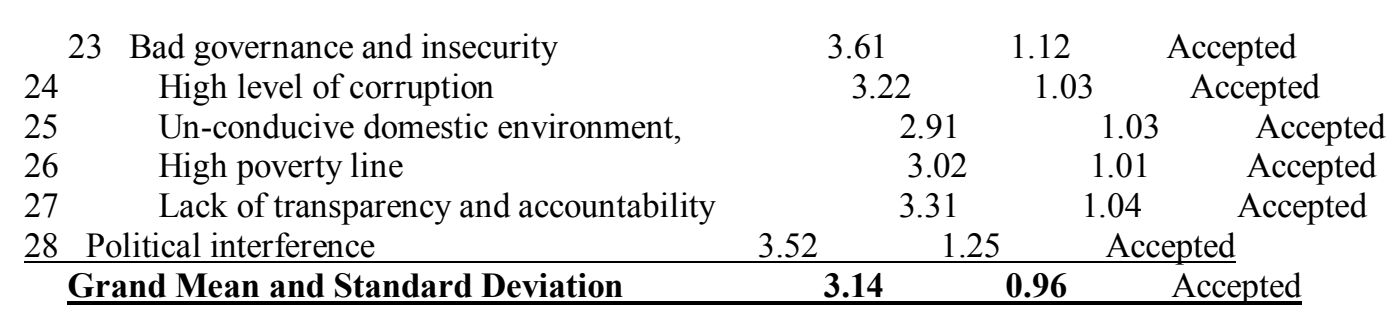

\section{Interpretation}

Table 4 showed that high mean scores of 3.42, 2.81, 2.51, 3.61, 3.22, 2.91, 3.02, 3.31 and 3.52 were recorded for items 20,21,23,24,25,26, 27, 28 and 9 respectively. These showed that out of 9 items listed only one item which is the reduction of money for current expenditures was rejected as being a challenge to the creation and operations of SWF in Nigeria, while eight (8) items were accepted as being the challenges that have faced or are still facing the SWF in Nigeria. Our finding is partially in line with what Majid (2012) revealed in his work which found that qualitative factors such as governance, policy framework, environmental stance, organizational structure, investment strategy, infrastructural position, decision making process and the overall state of the economy ultimately affect the creation, operation, performance and long term GDP growth rate of global SWFs investments. The work of Shleifer and Vishnu (1994) agreed with our findings, when it examined the role of political influence on firms and found that "public enterprises" including SWFs investments are highly inefficient and that their inefficiency is as the result of political interferences and pressures from the politicians who control them. Their results equally confirmed that the high level of corruption in some countries holding SWFs investment supports the idea that their objectives may not be driven by a risk-return profile. On the issue of lack of accountability and transparency being major hindrances to the operations of SWF in Nigeria, our findings are in complete agreement with the result of Chiejina, (2013) which found that transparency and accountability problems are the major issues that face Nigerian sovereign wealth funds investment. This assertion is in line with those of Yusuf (2011), Hassan (2013) and Utondu (2012) who concluded that to achieve increased SWF investment returns necessary to impact positively on the economy, all the stakeholders of the NSIA in this country need to permit a high degree of discipline in the running and management of the fund. Their studies advised that this can be achieved by ensuring that effort is made to see that the Fund operates in a leveling ground of no political manipulation and indecency of any sort. Though, the problem is not peculiar to Nigeria only, other countries especially the developing ones are also involved. Little wonder, April and Nathan (2012) in their study lamented that despite many notable exceptions and attempts by industry bodies in many countries to introduce standards and guidelines such as the sovereign wealth funds Limburg Model Transparency Index and the IMS's Santiago Principles, many sovereign wealth funds are still accused of operating with lack of investment transparency and accountability, hence do not come close to meeting acceptable standards of global corporate governance.

\section{Research Question 5}

To what extent has the sovereign wealth fund impacted to the GDP growth rate of Nigeria?

Table 5: Responses on the extent of contributions of the SWF on the GDP of Nigeria

\begin{tabular}{llccc} 
S/N & Items & $\mathrm{X}$ & $\mathrm{SD}$ & Decision \\
\hline 29 & Very High Extent & 0.31 & 0.04 & Rejected \\
30 & High Extent & 0.42 & 0.06 & Rejected \\
31 & Very Low Extent & 3.51 & 1.14 & Accepted \\
32 & Low Extent & 3.31 & 1.05 & Accepted \\
\hline Grand Mean and standard deviation & $\mathbf{1 . 8 9}$ & $\mathbf{0 . 5 7}$ & Rejected \\
\hline
\end{tabular}

\section{Interpretation}

Table 5 showed that item 31 has the highest mean score of 3.51 , followed by item 32 with a high mean score of 3.31; and these revealed that the respondents accepted strongly that the creation of SWF has not yet contributed meaningfully to the GDP growth rate of Nigeria economy. These findings are very much in line with the findings in the work of Sun and Heiko (2009) which found that there was no significant destabilizing effect of SWFs on equity markets, which is consistent with anecdotal evidence in the emerging economy of Indonesia. Their paper evaluates the short-term financial impact of SWF on selected public equity markets in Indonesia in which it was invested. Contrary to our result was the similar study of Rios and Louis (2009) which examined the emergency of sovereign wealth funds and its contributions to foreign direct investment in UK visa-a-visa the growth of the economy. Their work found that in the current world economy, sovereign wealth funds (SWFs) are hastily attaining significance as global financial players that impact positively on both the emerging and developed economies of the world. They argued that by engaging in foreign direct investment 
(FDI), SWFs can play a role in sustaining the global economy via improved growth and development. Equally in disagreement with our findings is the work of Roderick (2012) which examined the potential impact that SWF encompasses as a tool for economic growth. His study found that SWF has the potential to sustain longterm economic development through job generation and enhancement of exports, hence increased GDP especially in emerging economies.

Table 6: Regression Analysis of Sovereign Wealth Fund investment and the GDP Growth (a) Model Summary

\begin{tabular}{|l|l|l|l|l|l|}
\hline Model & R & R Square & Adjusted Square R & Std. Estimation error & Durbin-Watson \\
\hline 1 & $0.3705(\mathrm{a})$ & 0.2745 & 0.242 & 54800.5785 & 0.4575 \\
\hline
\end{tabular}

Predictor: (Constant) Sovereign Wealth Fund Investment

Dependent Variable: Component of GDP Growth Rate

(b) ANOVA

\begin{tabular}{|l|l|c|l|c|l|l|}
\hline Model & & Sum of Squares & Df & Mean Square & F & Sig. \\
\hline 1 & Regression & 10.033 & 1 & 10.033 & 28.504 & $.02(\mathrm{a})$ \\
& Residual & 15.222 & 39 & .194 & & \\
& Total & 25.255 & 40 & - & - & - \\
\hline
\end{tabular}

a. Predictor: (Constant), Sovereign Wealth Fund Investment

b. Dependent Variable: Component of GDP Growth Rate

(c) Coefficients

\begin{tabular}{|l|l|l|l|c|l|l|}
\hline & & Un-standardized Coefficients & Standardized Coefficients & T & Sig. \\
\hline Model & & B & Std. Error & Beta & \\
\hline 1 & (Constant) & 0.073 & 0.065 & -0.172 & 1.127 \\
& SWF investment to GDP & -2.803 & 0.005 & -0.235 & .26 \\
&
\end{tabular}

a. Predictor: (Constant), Sovereign Wealth Fund Investment

b. Dependent Variable: Component of GDP Growth Rate

\section{Interpretation}

From the result in table 6 the calculated t-value for the independent variable (SWF) is -1.568 while the critical t-value at 5 percent significant level is 2.35 percent.

Decision rule: Accept the null hypothesis if the calculated t-value is less than the critical value otherwise reject $\mathrm{H}_{0}$ and accept the alternate hypothesis.

Using the computed results as shown above, the calculated t-value is -1.568 and it is less than the 5 percent critical value of 2.35 . Therefore, we rejected the alternative hypothesis and accepted the null hypothesis which states that there is no significant positive relationship between sovereign wealth fund investment and economic growth in Nigeria. This is an indicative that there is a negative insignificant relationship between the sovereign wealth fund and the GDP growth rate in Nigeria, indicating that it has not contributed much to the growth of Nigerian economy. Sequel to this, our work concluded that sovereign wealth fund has not impacted significantly on the performance (GDP) of the Nigerian economy. This might be as a result of its newness in Nigeria. This result is in total agreement with the study of Yusuf (2011) and Uzowuru (2012) in which their findings affirmed that the creation of sovereign wealth fund in Nigeria is yet to impact on the growth (GDP) of the economy.

\section{Conclusion}

This study highlighted the effectiveness of the sovereign wealth fund in Nigeria in the growth and development of the economy from 2011 to 2013 with particular reference to the Nigerian Sovereign Investment Authority (NSIA). The study explored both theoretical and empirical evidence as bases for the research. From the empirical study it was revealed that the Sovereign Wealth Fund has gained significance recognition in the present global economy and has been acknowledged as a catalyst and a veritable channel for economic growth especially in developed economies but the contributions has been less than satisfactory in Nigeria. In other words, the investable fund has not impacted much on the GDP growth of the Nigerian economy owing to the fact that it is still new in Nigeria. However, the study has ascertained the purposes of creating sovereign wealth fund, its ownership structure, factors affecting its sustainable growth and performance, sources of funding, challenges and the perceived benefits of it to the economic growth of Nigeria and the welfare of the citizenry. Therefore, it becomes imperative that Nigerian Governments at all levels should ensure that the investment is not abused and this can only be delivered through insistency on accountability and transparency in the management of the fund. Only when this is done would the dream and dividends of the sovereign wealth fund 
investment become realities in Nigeria for the overall growth and development of the economy, hence increased foreign direct investment. In conclusion, considering the wide range of conflicting empirical studies on how sovereign wealth fund investment in developing countries affect the growth of the economy, distribution of income, infrastructural development, employment and some non-economic indicators like culture and politics, one cannot draw inference from them with any minimal acceptable level of confidence. Nevertheless, efforts should be geared towards nurturing the NSIA to attain sustainable growth and impact greatly to the economy because to whom much is given much is expected.

\section{Recommendations}

Though, Nigeria has spent more than half a century after the discovery of crude oil in commercial quantities without establishing a sovereign wealth fund. The costs of this delay in creating SWF to the country in terms of financial, social, economic, human development, revenue generation are quite enormous and cannot be accurately quantified. To regain the lost grounds, the public, the investors and the Nigerian governments at all levels should support and fast-forward efforts towards catching up with the global move geared towards appreciating the relevance of the SWF investment.

The study equally recommended that adequate supervision and monitoring of the fund should be demanded and pursed if the government wants to turn the birth of NSIA into fortune not misfortune for the growth of the economy and betterment of Nigerians. This can be achieved by ensuring that its affairs must not be mired in politics and should be transparently handled just like in developed nations of the world. The operations and affairs of the Fund should be divorced from the political interests and interferences if it is to deliver the required dividends. Moreover, for the SWF to succeed and deliver the required objectives in Nigeria it should be allowed to operate under the atmosphere of peace, hence, the federal government should not make it a national issue, states and local councils should be allowed to create and operate their own SWFs separately, quite separate from the national. Nigeria should learn from countries like United States where there is no national SWF, rather each state is free to setup its own sovereign wealth fund. For instance, state of South Carolina has Carolinian palm oil Trust Fund (agric-based) SWF; state of Alaska has the Alaska Petroleum Fund (oil and gas-based) SWF, the state of New Mexico has the New Mexico state investment Trust Fund (a noncommodity) SWF and the state of Wyoming has the Wyoming Mineral Trust Fund (a mineral-based) SWF.

Equally recommended by this paper is the serious need to resolve the issues surrounding the status of the Excess Crude Account (ECA) which has remained as the centre of the disagreements and conflicts among the different tiers of government of Nigeria. Excess oil reserves were previously allocated to the ECA which was set up in 2004 as a stabilization fund to meet the country's yearly budget deficits and to contribute to the development of local infrastructure. The constitutionality of the ECA has been brought into question and controversy. Unless the issues surrounding the states of the ECA are permanently resolved it would continually impact negatively on the ability of the NSIA to deliver the required dividends of SWF investment to the nation.

Again, transparency and accountability in reporting must be seen as major watch words and features of the Nigerian Sovereign Wealth Fund Investment Authority. Unfortunately, the indecent actions of some government officers who handle such laudable investment tarnish the image of the Nigerian sovereign wealth funds, thereby damaging the image of Nigeria internationally. As matter of facts, the problem does not lie so much with the magnitude of returns on sovereign wealth fund investment flows to Nigeria as with the form in which it is given but on accountability and transparency. This is a situation that clearly must be addressed for the long term benefits of SWF investment to be realized, it is not good enough for our government, the industry and the stakeholders of this nation to just sit back and accept the situation as it is. Something must be done to guide and control the situation, once this is achieved, there is every hope that the investment will deliver the required dividends as witnessed, testified and enjoyed by other countries. We could equally emphasize that sovereign wealth fund investment cannot contribute much to the economic growth and development of Nigeria if it is directed primarily to infrastructural development and future generations than to investment viable projects that promise violet returns. Sovereign wealth fund investment can be very effective if it is directed at improving and expanding managerial and labour skills necessary for efficient production of goods and services. Hence, the authorities concerned should try and nurture the Fund with sincerity of heart and determination to make the investment yield the required results for the benefits of all and sundry in Nigeria. Finally, efforts should be made to divorce the fund from politics, abuse and mismanagement such as embezzlement, misappropriation and diversion of fund for personal or sectional enrichment.

\section{Policy implications}

Given the results of our study, we therefore suggest for policy implementation that; it is logical to control and closely monitor the activities and operations of the Nigerian Sovereign Wealth Investment Authority (NSIA) in line with the laid down clearly defined policy objectives, policy targets and policy strategies so as to reap the dividends of such huge colossal investable fund. The activities of the anti-corruption agencies in 
Nigeria like the Economic and Financial Crimes Commission (EFCC) and the Independent Corrupt Practices Commission should be strengthened and directed directly to monitor closely the activities and operations of sovereign wealth fund investment. It is high time Nigeria as a giant of Africa put in leadership positions honest individuals who would serve as role models to manage sensitive areas like NSWA so as to minimize corruption with its negative impact on economic growth and development of Nigeria. Aside from this, with the up and down movement of sovereign wealth fund investment returns, Nigeria needs to design a policy framework that will make provision for juxtaposing it with foreign direct investment in order to maintain high levels of discipline necessary for increased returns and employment opportunities within the country. Obviously, the degree to which sovereign wealth fund investment makes or mars a developing country like Nigeria will be heavily influenced by the policy choice of the Federal Government.

\section{References}

[1]. Abdullah, G. (2009) "Institutional Investors and Sovereign Wealth Fund Investment” Journal of International Economics, (22), 221248.

[2]. Abuba, A.C. (2011) "Sovereign Wealth Fund and Economic Growth in Nigeria" Journal of Financial Studies, (12), 111-120 Afolabi, A.H. (2013) "An analytical evaluation of the relationship between Sovereign Wealth Fund and Economic Growth and Economic Freedom in Nigeria, Journal of Financial Studies, Vol. 5, No 12

[3]. Albesola, E., Serena, J. M. (2008), Reserves, Sovereign Wealth Funds and the Resilience of Global imbalances; Economic Notes by Halva Monte Dei Paschal Di Siena Spa, 37, 3.

[4]. Anderson, E. C. (2009). Take the Money and Run, Westport: Prater Security International.

[5]. April, M. L. and Nathan, M. (2012), "Sovereign Wealth Fund Investment and the Return-to-Risk Performance of Target Firms", Journal of Financial International, (8), 21

[6]. April, M.L., Bong. S.L. and Nathan, M. (2012). "Bilateral Political Relation and Sovereign Wealth Fund Investment, Journal of Corporate Finance Vol. 12, No.18.

[7]. Arizonan, J., Glick, R. (2008). SWF: Stylized Facts About their Determinant and Governor, Working Paper Published in December 2008, Available on http://www.nber.org/papers/w

[8]. Bahgat, G. (2008), "Sovereign Wealth Funds: Dangers and Opportunities", Journal of International Affairs, Vol. 84 , No. 6.

[9]. Balin, B.J. (2010), The Impact of Global Economic Crisis on Sovereign Wealth Funds, Asia - Pacific Economic Literature, the Australia National University and Blackwell Publishing Asia.

[10]. Barney, J.B. (2001), "Firm Resources and Sustained Competitive Advantage" Journal of Management, Vol. 5, No. 17.

[11]. Barney, J.B. and Hesterly, W.S. (2008), Strategy Management and Competitive Manager. New York: Reason Prentice Hall.

[12]. Beemer, J. (2010), Sovereign Wealth Funds SWFs. The end of the Free Market: Who wins the way between States and Corporation? New York: Penguin Group.

[13]. Bernstein, S. Scholar, A. and Lerner, J. (2009). "The investment strategies of sovereign wealth funds", working paper 14.861, National Bureau of Economic Research, Ambridge, Available at http://www.nber.org.paper/w14861.

[14]. Brown T.M. (2011) "Sovereign Wealth Fund Investment and the Return-to-Risk Performance of Target Firms". International Journal of Financial Studies, vol. 1, No. 12.

[15]. Chandra, S., Shadwell W.G. (2007), Crossing Disciplinary Boundaries. Applying Financial Portfolio Theory To Model The Organization of the Self-Concept, Journal of Research in Personality, (41) 2.

[16]. Chiejina, N. (2013), Nigerians to Pay for Amenities Financed with Sovereign Wealth Fund. The Nation Newspaper, 30 June, pp. 12

[17]. Daniel, D. and Brickman, P. (2001). "Block Ownership of Sovereign Wealth Fund and Firm- Specific Information" Journal of Banking and Finance, Vol. 12, No. 33 .

[18]. Das, U. Miserere, A. and Vander Horal, H. (2010). Economics of Sovereign Wealth Funds: Issues for Policymakers, Washington: International Monetary Fund.

[19]. Gbogbo, B.E. (2012), Nigeria Sovereign Wealth Funds to Start Investing in March, This Day,30 June, pp.10.

[20]. Gbogbo, B. (2012), Nigeria Sovereign Wealth funds to Start Investing in March Bloomberg, Com. Retrieved 30 June.

[21]. Grieve, M.T. (2008). "Hedge Financial Activism, Corporate Governance, and Firm Performance" Journal of finance, $12,63$.

[22]. Hassan, T.S. (2009), Sovereign Wealth Funds. Their Investment Strategies and Performance Paper Available at http://ssrn.com/abetrad.=12-62383.

[23]. Helene, R. (2008), “the Effect of Sovereign Wealth Funds” Investigation on Stock Markets” Diss. University Park (Quest Nanette).

[24]. Hellene, H. and Lund-lad, I. (2008). A Survey of Blok holders and Corporate Control” Economic Policy Review (9), 112.

[25]. Inokotong, J. (2013), Nigerian Sovereign Investment Authority Unfolds Areas of Interest. This Day, 30 May, pp.10

[26]. IWG (International Working Group of Sovereign Wealth Funds), 2008, Sovereign Wealth Funds; Generally Accepted principles and Practices - "Santiago Principles" (Washington)

[27]. Jen, S. (2007). When financial Institutions are large shareholders; The Role of Macro corporate Governance Environments; Journal of Finance, (8) 61.

[28]. Kottler, K and Lei, D. (2011). "Friends or foes. Target Selection Decisions of sovereign wealth funds and their consequences. "Journal of Financial Economics, (12) 101-122.

[29]. Lam, D and Rossi, T. (2010). "Dyadic Military conflict, Security Alliances, and Bilateral FDI Flows" Journal of International Studies. Vol. 5 No. 41.

[30]. Majid A. (2012) "Analytical study of Sovereign Wealth Funds, Strategies and Policies: a case study if Oman Sovereign Wealth Fund. A Thesis Submitted for the Degree of Doctor of Philosophy Brunel Business School Brunel University.

[31]. Malan, R. (2013), Becoming Boring: Lessons from Modern Monetary Policy for Sovereign Wealth Funds. Paper presented at the Biennial Conference of the Economic Society of South Africa, University of the Free State, Bloemfontein, South Africa. September.

[32]. Peters, A.C, (1998), the role of sovereign wealth fund in Economic Growth in Thailand” Journal of Policy modeling, 22 , (4); 88-98.

[33]. Rice, K. (2013), Volatility Delays Investment from Nigeria Sovereign Wealth Fund. Financial Times, Nigeria: Daily Times Publication 29 June pp. 12

[34]. Rozanor .T. (2006) A Blueprint for Sovereign Wealth Fund Best Practices, London: Peterson Institute.

[35]. Ruth Rios, M. and Louis B., (2009)."The Emergency of Sovereign Wealth Funds as Contributors of Foreign Direct Investment". Oxford Business and Economics Conference Program.

[36]. Schlerfer, A., Vishnu, A. (1994), "Politicians and Firms" Quarterly Journal of Economics, Vol.12, No 109. 
[37]. Sun, T. and Heiko, H. (2009), Sovereign Wealth Funds and Financial Stability - An Event Study Analysis International Monetary Fund Working Paper WP/239.

[38]. Ujah, E. (2013). Sovereign Wealth Fund Takes Off with \$1bn Grant. Vanguards, 14 June,pp.12

[39]. Utondu, C.C. (2012) the impact of sovereign wealth fund on the performance of the Nigerian economy, Journal of Financial Studies, Vol. 8, No. 7

[40]. Veljko, F., Bernard, B. and Merganser, W. (2008). The Financial Impact of Sovereign Wealth Fund Investments in listed companies. http://faculty.staff.eu.edu/m/william.l.megginson.i

[41]. Wolf, S. (2007), Crossing Disciplinary Boundaries, Applying Financial Portfolio Theory to Model the Organization of the SelfConcept, Journal of Research in Personality, 41 (2), 1-9

[42]. Yusuf, A. (2012) "Sovereign Wealth Fund: Its Benefits to Nigeria, An empirical investigation" International Research Journal of Finance and Economic Issues, 56; (5), 55-68. 